\title{
Relationship between Provincial Competitiveness Index and Development of Provincial Enterprises
}

\author{
Vương Đức Hoàng Quân
}

HCMC Institute for Development Studies - quan_vdh@yahoo.com

\section{ARTICLE INFO}

Article history:

Received:

April 12, 2014

Received in revised form

July 7, 2014

Accepted:

Sep 30, 2014

Keywords:

PCI, local government,

enterprise, economic

development.

\section{ABSTRACT}

Employing data for the years 2006-2011, the research analyzes the relationship between Provincial Competitiveness Index (PCI) ranking and development of enterprises in certain Vietnamese provinces. The results show that the data do not demonstrate the relationship between the PCI ranking and indexes of development of enterprises. This implies that great caution should be taken when interpreting the PCI ranking of a province, especially in treating the PCI as a driving force for the provincial economic development. 


\section{PROBLEM STATEMENT}

Economic operation of local government plays an important role among the factors affecting regional economic development. While location and natural resources are considered 'hard' advantages or unchangeable advantages, economic operations are referred to as 'soft' advantages - changeable advantages based on capacity, level of commitment, willingness and effort of provincial governments.

With the aim to measure and assess economic governance of provincial governments, non-governmental organizations and Vietnam Chamber of Commerce and Industry (VCCI) have collaborated on the design and examination of Provincial Competitiveness Index (PCI) since 2005, conducive to change the awareness of 'soft' advantages and promote economic development among provinces, especially those of private sector.

Nevertheless, during the implementation reports on the PCI indicate some matters worthy of notice. No scientific research has so far proved the relationship between the PCI and provincial economic development through the analysis of authentic data in Vietnam.

The analysis of this nexus necessitates sufficient research particularly on the relationship between the PCI and provincial GDP. However, after thoroughly considering some difficulties in unifying definitions of provincial GDP in theory and practice, the author suggests another approach for a research on the relationship between the PCI and provincial economic development: enterprise-based one. Enterprises are the basis of such development; thus, the existence of the relationship between the PCI and development of enterprises implies the existence of the PCI's relationship with provincial economic development. In addition, the PCI is conditional upon enterprise-based examination so that analyzing this relationship can be highly reliable.

The study aims to test the relationship between the PCI and development of enterprises in certain provinces/cities, thereby framing a research question: Is there a relationship between high PCI ranking and strong development of enterprises?

\section{DEFINITIONS AND TERMS}

\subsection{Provincial Competitiveness Index}


Provincial Competitiveness Index (PCI) is exploited as an important tool for measuring and assessing economic governance and operation in Vietnam's 63 provinces and cities from the perspective of nine factors greatly affecting the development of private sector, including the following:

- Entry costs,

- Land access and security of tenure,

- Transparency and access to information,

- Time requirements for procedures,

- Informal charges;

- Proactive and creative provincial leadership,

- Business support services,

- Labor training, and

- Legal institutions.

According to VCCI (2009), the PCI approach involves four noticeable features:

First, by normalizing scores around Vietnam's best available practices in economic governance without any reference to ideal yet unattainable governance standards, the PCI is designed to encourage provincial governments to improve their performance. For each indicator, 'star' or top-leading provinces can be then identified and any province also possibly achieves perfect PCI score of 100 by applying these best practices to economic governance.

Second, the PCI indicates sound governance practices obtained at the provincial level by removing the effects of initial conditions (fundamental factors contributing to economic growth in a province and nearly unchangeable in the short term, such as geographical location, infrastructure, market size, and human resources).

Third, by comparing/contrasting economic governance practices to economic performance, the PCI estimates the importance of best practices in attracting investment and growth. This previous study demonstrates a correlation between best practices in economic governance and business performance, as well as provinces' improvement in welfare profits. This ultimate relationship is obviously crucial since it signifies that friendly policies and innovations encourage businesses to perform in line for the benefits of not just owners and workers but also society by creating more employment and increasing income for the economy as a whole. 
Fourth, indicators making the PCI up are actionable. These particular items allow provincial officials to target and monitor improvement during their implementation of economic governance. In addition, the indicators are action-worthy because they are considered key policies to a success in their business performance.

\subsection{Development of Enterprises}

There are many different standards to assess development of enterprises, most of which focus on an increase in business size and performance. In terms of business size, selected standards are capital, labor, fixed assets, long-term financial investment, market share, etc. In terms of business performance, those include revenue, profits, labor productivity, income, etc.

The aforementioned standards are still appropriate to assess firms as a whole. However, it is very difficult to gather data, so the paper employs only four indicators to assess development of provincial enterprises. According to GSO, these are defined as follows:

- Quantity: total number of enterprises in operation at the period of 31 December by each province,

- Capital: total annual average capital of enterprises by each province,

- Fixed assets and long-term financial investment: total fixed assets and long-term financial investment of enterprises at the period of 31 December by each province,

- Net revenue: total revenue of enterprises derived from selling products, goods, and providing services after various types of tax (excise tax, export tax, value added tax in accordance with direct method) and revenue deductions. Net revenue does not include financial activities income and such extraordinary income as liquidation, sold and transferred assets, income from a breach of contract, income from bad debts, etc.

In this study, development of enterprises is known as an increase in one of the four indicators above, and the larger the increase, the more the development.

\section{RESEARCH METHODS}

\subsection{Research Approach}

As an effective tool to measure and assess provincial economic governance, higher PCI expresses better economic operation and governance. This leads to more efficient economic activities in provinces in general and in enterprises in particular. 
GDP produced by enterprises, according to the data collected by GSO, accounts for at least $60 \%$ of total GDP during the period 2006-2011. As with the fact that enterprises significantly affect other economic sectors, the changes in their governance can make strongly great effects on total provincial GDP.

In search of the level of correlation, the author compares the PCI with different aspects of provincial enterprises, allowed by the scope of this study. This comparison to some degree contributes to clarify the representative and role of PCI in provincial development. Yet, the study does not examine the causal relationship between the PCI and development of enterprises because:

- Whether the PCI can measure and assess provincial economic operation and governance is still a query.

- The impact of local economic governance on the outcome of economic development has yet to be assessed.

- The causal relationship between development of enterprises and provincial GDP has not yet come to light due to the impact of other determinants.

Accordingly, the study aims to analyze the relationship between the PCI and development of enterprises. Research hypothesis, therefore, is: the relationship will exist if the PCI does represent provincial economic operation and governance.

\subsection{Analytical Framework}

PCI is not examined by many researchers due to its specific characteristics. Efforts to find out researches on PCI seem unachievable. In addition, most experts merely end up evaluating the rationality of PCI indicators, not their effects on provincial economic development. The analytical framework, hence, is based on hypotheses and arguments presented in the sections problem statement and research approach.

Provincial economic governance is represented by PCI indicators in this analytical framework, which is deemed the target for a set of these indicators. Provincial economic development can be affected by economic operation and governance, especially development of regional enterprises performed in four aspects: total number of enterprises, total capital, total fixed assets and long-term financial investments, and gross net revenue. 
Thus, there exists a relationship between PCI and the other four indicators denoting development of enterprises. In order to examine this, the study proceeds to analyze the correlation between provincial PCI ranking and growth ranking of those indicators.

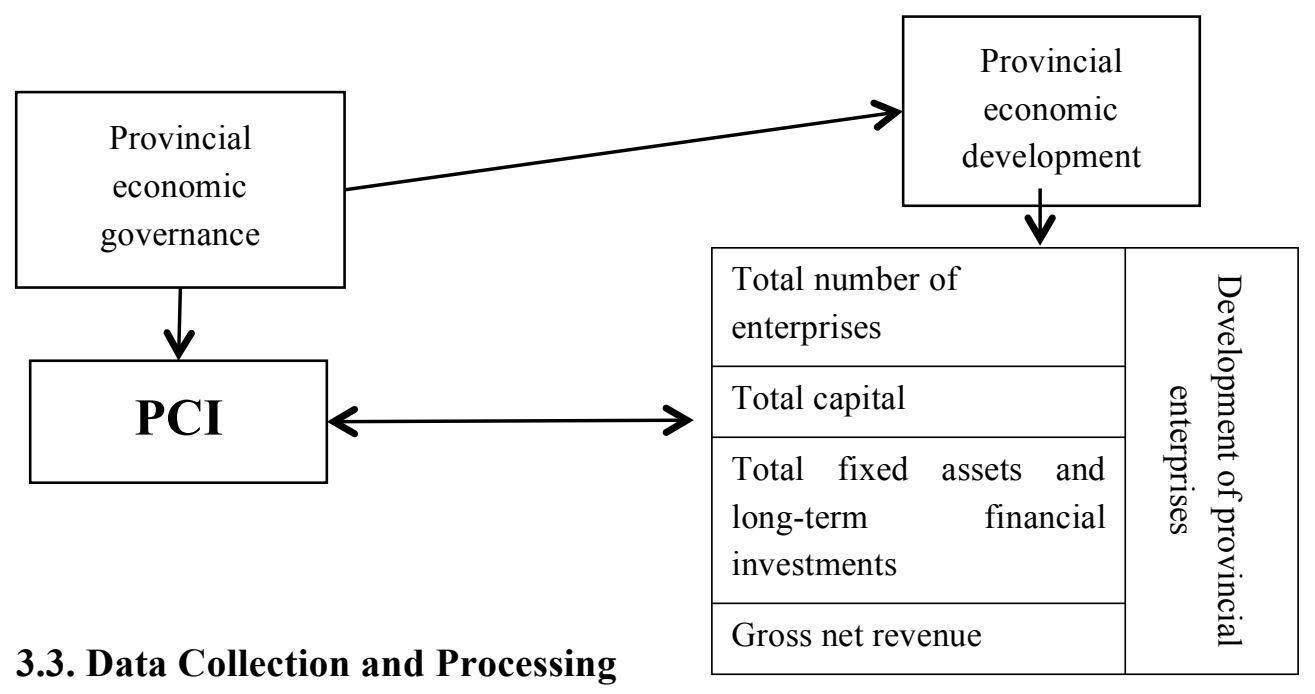

Data are collected from:

- The website http://www.pcivietnam.org/ for PCI data during 2006-2011, and

- Statistical Yearbooks from 2006 to 2011 for dataset on enterprises.

Hà Tây province, in this period, was merged into Hà Nội; therefore, the data were only gathered from 2006 to 2007, which results in such impossibility to employ 2008's data compared to that of 2007.

Enterprises' growth rates are calculated by the data collected from Statistical Yearbook, and then provinces are ranked in descending order, from the ones with higher growth rate to those with lower growth rate. This arrangement is implemented to measure the correlation of enterprises' growth rates with the PCI ranking.

Lag-0, lag-1 and lag-2 are used in the calculations, denoting the correlations of the PCI ranking in year $i$ with enterprises' ranking in years $i, i+1$ and $i+2$ respectively. The introduction of these lags into the calculations aims to add accuracy to the effects of the PCI because improving PCI cannot exert immediate impact on development of provincial business but a certain amount of time is required to change the competitiveness into specific effects on the development of provincial enterprises. 


\section{RESULT ANALYSIS}

\subsection{Provincial Enterprises}

The provinces gaining specific advantages and good communication can easily attract investments by different enterprises. Being also one of communication methods, higher PCI can become a desirable factor for enterprises' investments.

Concerning average lags, a strong correlation seems to imply longer lags. At lag-0, the correlation indicators of each year are at an average of $0.63 \%$, and of $6.66 \%$ and $9.63 \%$ at lag-1 and lag-2 respectively. The uniformity of these lags' signs indicates a positive relationship between PCI ranking and development of enterprises.

However, there no more exists positive sign in detailed examination of each year's indicators. Heterogeneous signs of correlation coefficients are worthiest of attention. Among 15 correlations coefficient, 8 are negative and 7 are positive. In addition, a high fluctuation (from $-18.53 \%$ to $+34.56 \%$ ) causes difficulty to the identification of the level of correlation between the PCI ranking and the ranking of increasing enterprise growth, to wit: there exists no correlation between these.

Table 1. Correlation between PCI Ranking and Growth Rate of Provincial Enterprises

\begin{tabular}{|c|c|c|c|c|c|c|}
\hline PCI Enterprises & 2006 & 2007 & 2008 & 2009 & 2010 & 2011 \\
\hline 2006 & $-3.61 \%$ & $-9.07 \%$ & $-9.25 \%$ & & & \\
\hline 2007 & & $-3.30 \%$ & $-7.86 \%$ & $-1.67 \%$ & & \\
\hline 2008 & & & $0.81 \%$ & $19.24 \%$ & $14.87 \%$ & \\
\hline 2009 & & & & $6.50 \%$ & $-0.99 \%$ & $34.56 \%$ \\
\hline 2010 & & & & & $-18.53 \%$ & $31.98 \%$ \\
\hline 2011 & & & & & & $21.91 \%$ \\
\hline Average of lag- 0 & \multicolumn{6}{|c|}{$0.63 \%$} \\
\hline Average of lag-1 & \multicolumn{6}{|c|}{$6.66 \%$} \\
\hline Average of lag-2 & \multicolumn{6}{|c|}{$9.63 \%$} \\
\hline
\end{tabular}

Source: Author's calculations based on data of PCI and Statistical Yearbooks 


\subsection{Total Capital of Corporate Sector}

While the quantity of enterprises reflects provinces' attraction, the increase in capital represents enterprises' belief in provincial policies and their business performance. When enterprises have the trust in provincial economic governance and profit from their business, they would willingly increase their capital in various ways such as reinvesting by reserved profits or extending their activities by using loan capital. If the higher PCI ranking is expected to enhance the efficiency in provincial economic governance, it will lead to the greater increase in total capital of provincial enterprises.

Average lags obviously signify a tendency as opposed to the correlation between the PCI and the increase in a quantity of enterprises, i.e. the longer the lags, the lower the correlation coefficients. There are hardly uniformity of signs of these coefficients (the case reveals both negative and positive ones). Additionally, the values have very low average. Absolute value of the highest value, for example, is at an average of $7.7 \%$.

The average of correlation coefficients is highest when the lag equals 0 , implying that there are concurrent existence of PCI and capital increase. However, correlation coefficients reveal negative signs. Particularly, the correlation between the PCI ranking and level of capital increase is at the rate of $-2.75 \%$ in 2009 . At other lags, in addition, uniformity of signs does not ring true.

Thus, the correlation between PCI ranking and the growth rate of capital of enterprises in same province remain insignificant.

Table 2. Relationship between PCI Ranking and Growth Rate of Capital of Provincial Enterprises

\begin{tabular}{|c|c|c|c|c|c|c|}
\hline PCI & 2006 & 2007 & 2008 & 2009 & 2010 & 2011 \\
\hline 2006 & $8.22 \%$ & $-0.87 \%$ & $-9.05 \%$ & & & \\
\hline 2007 & & $17.04 \%$ & $-1.87 \%$ & $-9.85 \%$ & & \\
\hline 2008 & & & $5.68 \%$ & $10.18 \%$ & $17.38 \%$ & \\
\hline 2009 & & & & $-2.75 \%$ & $3.65 \%$ & $-0.52 \%$ \\
\hline 2010 & & & & & $15.79 \%$ & $-1.53 \%$ \\
\hline
\end{tabular}



Average of lag- 0
$7.70 \%$
Average of lag-1
$1.91 \%$
Average of lag-2
$-0.51 \%$

Source: Author's calculations based on data of PCI and Statistical Yearbooks.

\subsection{Fixed Assets and Financial Investment of Corporate Sector}

Similar to capital, fixed assets and long-term financial investment indicate an agreement between enterprises and their provincial governments. The increase in their fixed assets and long-term financial investment implies that enterprises wish to give their long-term commitment to region, in which PCI is a contributory factor.

Signs of averages of correlation coefficients corresponding to the lags are positive. At lag-1, the highest average is $10.63 \%$, whereas at lag-0 and lag-2, the average is very low (less than 6\%). The consideration of constituent correlation coefficients shows that signs of these are inclined to be negative regarding the global economic crisis 20082009. The tendency, however, is not obvious. This is because there still exists a positive correlation coefficient. Otherwise, the fluctuation in correlation coefficients is very large (from $-15.36 \%$ to $+19.14 \%$ ).

Accordingly, the relationship between PCI ranking and the growth rate of fixed assets and long-term financial investments of provincial enterprises have yet to manifest it.

Table 3. Relationship between PCI Ranking and Growth Rate of Fixed Assets and Long-term Financial Investments of Provincial Enterprises

\begin{tabular}{|c|c|c|c|c|c|c|}
\hline PCI Fixed Assets & 2006 & 2007 & 2008 & 2009 & 2010 & 2011 \\
\hline 2006 & $8.45 \%$ & $13.25 \%$ & $-4.16 \%$ & & & \\
\hline 2007 & & $31.30 \%$ & $-1.30 \%$ & $-21.04 \%$ & & \\
\hline 2008 & & & $2.97 \%$ & $6.57 \%$ & $17.91 \%$ & \\
\hline 2009 & & & & $-15.36 \%$ & $19.14 \%$ & $18.46 \%$ \\
\hline 2010 & & & & & $6.13 \%$ & $15.48 \%$ \\
\hline
\end{tabular}




\begin{tabular}{lc}
\hline Average of lag-0 & $5.84 \%$ \\
Average of lag-1 & $10.63 \%$ \\
Average of lag-3 & $2.79 \%$ \\
\hline
\end{tabular}

Source: Author's calculations based on data of PCI and Statistical Yearbooks.

\subsection{Gross Net Revenue of Corporate Sector}

Net revenue demonstrates business performance of a provincial enterprise. If a province has a high PCI rank, the rate of an increase in its net revenue is expected to be higher than other provinces.

Nevertheless, the data do not reveal this tendency. The averages of correlation coefficients as well as constituent ones have different signs at each respective lag. Moreover, the average values of correlation coefficients are approximately 5\%, whereas the fluctuation is still large (from $-33.47 \%$ to $21.05 \%$ ).

The aforementioned discussions conclude that the effects of PCI ranking on the growth rate of net revenue of provincial enterprises are not realized.

Table 4. Relationship between PCI Ranking and Growth Rate of Net Revenue of Provincial Enterprises

\begin{tabular}{|c|c|c|c|c|c|c|}
\hline PCI Revenue & 2006 & 2007 & 2008 & 2009 & 2010 & 2011 \\
\hline 2006 & $2.20 \%$ & $-12.17 \%$ & $-3.74 \%$ & & & \\
\hline 2007 & & $-14.44 \%$ & $-1.77 \%$ & $-33.47 \%$ & & \\
\hline 2008 & & & $7.41 \%$ & $14.74 \%$ & $9.90 \%$ & \\
\hline 2009 & & & & $-24.46 \%$ & $6.28 \%$ & $4.12 \%$ \\
\hline 2010 & & & & & $10.42 \%$ & $16.35 \%$ \\
\hline 2011 & & & & & & $21.05 \%$ \\
\hline Average of lag- 0 & \multicolumn{6}{|c|}{$0.36 \%$} \\
\hline Average of lag-1 & \multicolumn{6}{|c|}{$4.69 \%$} \\
\hline Average of lag-2 & \multicolumn{6}{|c|}{$-5.80 \%$} \\
\hline
\end{tabular}

Source: Author's calculations based on data of PCI and Statistical Yearbooks. 


\subsection{Comparison of PCI Ranking between Provinces and Cities: Đà Nẵng, Lào Cai, HCMC and Đắk Nông}

Đà Nẵng and Lào Cai have held the highest PCI ranking in the country over many years (at the average of 2 and 6.3/63 provinces of Vietnam respectively, according to 2006-2011 national PCI rankings). Meanwhile, HCMC, with its highest GDP rate, has been at the average ranking of 19.3 out of 63 provinces, and Đắk Nông, as the province with the lowest ranking, features an average of 59.5/63.

In some aspects of Vietnamese economy, the similarity between Lào Cai and Đắk Nông is that both are located far away from big economic centers, whereas HCMC and Đà Nẵng, centrally controlled municipalities, are regarded as key centers for economic development. A query is consequently raised: Does the difference in the PCI ranking touch off unbalance in provincial enterprises' development?

Table 5. PCI Ranking of Provinces over Years

\begin{tabular}{cccccccc}
\hline PCI & $\mathbf{2 0 0 6}$ & $\mathbf{2 0 0 7}$ & $\mathbf{2 0 0 8}$ & $\mathbf{2 0 0 9}$ & $\mathbf{2 0 1 0}$ & $\mathbf{2 0 1 1}$ & TB \\
\hline Đà Nẵng & 2 & 2 & 1 & 1 & 1 & 5 & 2.0 \\
Lào Cai & 6 & 5 & 21 & 3 & 2 & 1 & 6.3 \\
Đắk Nông & 63 & 64 & 46 & 62 & 63 & 59 & 59.5 \\
HCMC & 7 & 10 & 40 & 16 & 23 & 20 & 19.3 \\
\hline
\end{tabular}

Source: Collected data from Website www.pcivietnam.org

Table 5 illustrates that the smallest increase in quantity of enterprises typifies Lào Cai province while the others have approximately equal increase. In terms of capital, Đà Nẵng have the lowest growth rate while Đắk Nông features the highest, creating the gap of up to $14 \%$. On the other hand, the large gap in economic size between provinces (total capital of enterprises in Đà Nẵng is nearly 10 times greater than in Đắk Nông) has a significant impact on the growth rate of total capital.

Table 6. The Number of Enterprises and Total Capital

\begin{tabular}{cccc|ccc}
\hline & \multicolumn{3}{c|}{ The number of enterprises } & \multicolumn{3}{c}{ Capital (VND billion) } \\
\hline Year & 2005 & 2011 & Average/year & 2005 & 2011 & Average/year \\
Đà Nẵng & 2,621 & 8,050 & $20.57 \%$ & 28,534 & 127,145 & $28.28 \%$ \\
Lào Cai & 638 & 1,022 & $8.17 \%$ & 4,109 & 21,643 & $31.91 \%$
\end{tabular}




\begin{tabular}{cccc|ccc} 
Đắk Nông & 227 & 656 & $19.35 \%$ & 1,604 & 13,648 & $42.88 \%$ \\
HCMC & 31,292 & 104,299 & $22.22 \%$ & 600,889 & $3,863,043$ & $36.36 \%$ \\
\hline
\end{tabular}

Source: Collected data from Statistical Yearbook

Similarly, data on fixed assets and net revenue do not reflect the difference in PCI ranking; even there exists the reverse between the top-performing province and the bottom-performing one. Given fixed assets, the average of increase in Đắk Nông is $61.54 \%$ per year while the average in Đà Nẵng is only $35.7 \%$ per year. The two approximate averages of $32.80 \%$ and $36.43 \%$ are found in Lào Cai and HCMC respectively. The case of net revenue, on the other hand, reveals that Lào Cai has the highest annual increase of $42.73 \%$ compared with the lowest one of $36.43 \%$ found in Đà Nẵng. This rate revealed by HCMC and Đắk Nông is $31.27 \%$ and $37.58 \%$ respectively.

Table 7. Fixed Assets \& Long-term Financial Investment and Net Revenue of Enterprises (VND billion)

\begin{tabular}{cccc|ccc}
\hline & \multicolumn{2}{c}{ Fixed assets and long-term financial investment } & \multicolumn{3}{c}{ Net revenue } \\
\hline Year & 2005 & 2011 & Average/year & 2005 & 2011 & Average/year \\
Đà Nẵng & 11,283 & 70,447 & $35.70 \%$ & 40,205 & 135,072 & $22.38 \%$ \\
Lào Cai & 1,823 & 9,998 & $32.80 \%$ & 3,375 & 28,539 & $42.73 \%$ \\
Đắk Nông & 527 & 9,363 & $61.54 \%$ & 2,580 & 17,495 & $37.58 \%$ \\
HCMC & 198,054 & $1,277,342$ & $36.43 \%$ & 544,363 & $2,784,983$ & $31.27 \%$ \\
\hline
\end{tabular}

Source: Collected data from Statistical Yearbooks

In brief, all of the four indicators used to measure enterprises' development do not reflect the provincial PCI ranking. Data, in other words, do not reveal any differences between the top-performing province (Đà Nẵng) and the bottom-performing one (Đắk Nông). Specifically, the efficient of PCI as a tool to measure enterprises' development needs be made more obvious and proper.

\subsection{Discussion}

Through the analyses of correlation coefficients, the paper comes up with unattainable evidence for the correlation between the PCI ranking and provincial enterprises' development. 
Particularly, it examines the relationship between the PCI ranking and such indexes of development of enterprises as number of enterprises, total capital, total fixed assets and long-term financial investment, and gross net revenue. The findings indicate no tight correlation and no uniformity in coefficients' signs.

In addition, hardly any correlation between the PCI ranking and provincial enterprises' development has been identified among some typical provinces. Developed enterprises in such top-ranked provinces as Đà Nẵng and Lào Cai have yet to outnumber those in the bottom-ranked province Đắk Nông, which, for several indicators, even surpasses Đà Nẵng and Lào Cai. Moreover, a brief mention of comparison between HCMC and other provinces concludes that it is impossible to predict the PCI ranking based on the data on development of provincial enterprises.

In search of the causes to those findings, the author explores three main reasons as follows:

\section{PCI reflects insufficiently provincial economic governance.}

One of the plausible reasons lies in the method of PCI's investigation. Considering the questionnaire about access to land, for example, three main indicators that could be identified include: (i) administration; (ii) land stability and adequate compensation; and (iii) access to land. It is obvious that hardship arises concerning such comparison between a province that has few enterprises but large land fund with the one that has many enterprises but very limited land fund. The case of Đà Nẵng and HCMC would be a perfect illustration.

Table 8. Class of Land by Purpose (1,000 ha)

\begin{tabular}{lcc}
\hline & Đà Nã̃ng & HCMC \\
\hline Total area & 128.6 & 209.5 \\
Agricultural land & 7.8 & 72.1 \\
Forestry land & 59.1 & 34.1 \\
Specially used land & 41.0 & 33.0 \\
Homestead land & 6.1 & 23.7 \\
\hline
\end{tabular}

Source: Statistical Yearbook 2011

Apparently, although the number of enterprises in HCMC is approximately 10 times as many as that in Đà Nẵng, its less specially used land causes difficulties in 
giving license, making land valuation and providing favorable conditions for enterprises to access to land. More importantly, access to land is not a factor that provincial governments can strictly control. The enterprises in Đà Nẵng gain more convenience in finding their own locations for business operation than those in HCMC. This can affect enterprises' evaluation and exert significant impact on the comparison between provinces.

Apart from provincial economic governance, other factors must be considered in an effort to promote provincial economic development, or at least to impact development of provincial enterprises.

Table 9. Foreign Investment Projects Registered in Provinces in 2011

\begin{tabular}{lcc}
\hline & Number of projects & Total registered capital (US\$ million) \\
\hline Lào Cai & 2 & 28.8 \\
Đồng Tháp & 1 & 10.0 \\
Đà Nẵng & 37 & 477.8 \\
Bình Dương & 80 & $1,006.2$ \\
Đồng Nai & 33 & 850.9 \\
HCMC & 359 & $3,144.6$ \\
\hline
\end{tabular}

Source: Statistical Yearbook 2011

What results in an enterprise's decision to choose a location for doing their business? According to the theory of economic geography, selecting a business location is based on an optimal calculation on the distance from that place to material areas and markets. This impact is partly recognized through data on foreign investment into provinces.

Such provinces with inconvenient traffic as Đồng Tháp and Lào Cai (ranked $4^{\text {th }}$ and $1^{\text {st }}$ in 2011-PCI ranking respectively) are not much attended by foreign investors, which also holds true for domestic ones.

On the contrary, provinces with convenient traffic and population density like Đà Nã̃ng and HCMC can receive much more attention from investors. Furthermore, due to being near the area of dense population, Đồng Nai and Bình Dương are highly attractive in spite of not being developing centers as the others. 
Provincial economic governance is considered a critical factor to attract enterprises. In addition, many different factors creating the general impact should be paid due attention in the effort to develop provincial economy rather than to increase the PCI.

Enterprises' development inconsiderably impacts on provincial economic development.

This can also be considered a cause but is of very little likelihood. As GDP produced by enterprises' business performance, according to statistical data, accounts for over $60 \%$ of total national GDP, the impact of enterprises' business performance on provincial economic growth rate cannot be negligible.

In short, two major reasons causing the results, as was mentioned above, are: (i) the PCI can insufficiently reflect provincial economic governance; and (ii) there exists many different factors worthy of attention in the effort to promote provincial economic development besides provincial economic governance.

\section{CONCLUSIONS AND RECOMMENDATIONS FOR FUTHER STUDIES}

\subsection{Conclusions and Recommendations}

As a complete set of index to assess the capacity of provincial governments for provincial economy governance, the PCI has raised a general expectation that improving it would attract both domestic and foreign investments.

However, the above results show that a hypothesis of the relationship between the PCI and provincial economic governance has not been actually affirmed. This means, a province having a high PCI ranking does not necessarily imply that development of its enterprises is greater than enterprises' in a province having a lower PCI ranking. In this paper, the development of enterprises depends on four factors: the quantity of enterprises, total capital, total fixed assets and long-term financial investments, and gross net revenue.

One shortcoming of this study is that it merely identifies the relationship between the PCI and enterprises' development. To determine the reasons for this case, more indepth studies are needed. As was indicated by the findings, we should adjust our view of the PCI as a single critical index to measure provincial economic governance.

Some recommendations are put forward as follows:

- Provincial governments shall: (i) treat PCI results with caution; (ii) not consider PCI as either a very important or a unique index to assess provincial economic 
governance; and (iii) apart from improving the PCI, focus on solutions to key enterprises development.

- PCI surveying organizations shall: (i) reconsider significance of the reasonable given indicators; and (ii) more sufficiently investigate both soft and hard advantages for an overall view (soft advantage becomes essential only when it makes best use of hard advantage; thus, a single survey on soft advantage will hinder the analysis of its causal relationship with provincial economic development).

- Provincial enterprises shall: (i) not pay too much attention to the PCI but various factors in determination of business locations; and (ii) take notice of small internal factors instead of large-scaled ones in handling the results of PCI (determine which index is necessary to propose proper solutions).

- Policy makers shall do more thorough researches to determine whether or not the PCI actually reflects provincial economic governance.

\subsection{Shortcomings and Suggestions for Further Studies}

The paper mainly applies data gathered from GSO and VCCI. Thus, other data are highly recommended for further researches to analyze the relationship between the PCI and provincial development.

Regarding data analysis, the number of lags is a maximum of 2 years. In reality, the period of time longer than 2 years is necessary to effectively promote competitiveness expressed by its relationship with degree of development of provincial enterprises. Further researches should take into consideration lags of over two years to fully examine the relationship between the PCI and provincial enterprises' development, as well as to determine the number of lags for maximum correlation, if any.

In addition, the study is conducted by arguments and approaches to three hypotheses: (i) the PCI in association with provincial economic governance; (ii) the reverse case; and (iii) economic development in close association with development of enterprises.

To accept or reject the PCI, therefore, other researches on various aspects should be conducted in order to test its relationship with provincial economic governance 


\section{References}

Dự án Chỉ số Năng lực Cạnh tranh cấp tỉnh PCI (2014), "Giới thiệu PCI” available at http://www.pcivietnam.org/gioi-thieu-pci-c2.html

Dự án Chỉ số Năng lực Cạnh tranh cấp tỉnh PCI (2014), "Phương pháp PCI", available at http://www.pcivietnam.org/phuong-phap-c9.html

GSO (2013), Sụ phát triển của doanh nghiệp Việt Nam giai đoạn 2006 - 2011, Thống Kê Publisher, Hà Nội.

GSO (2012), Niên giám thống kê năm 2011, Thống Kê Publisher, Hà Nội.

GSO (2012), “Các ấn phẩm đã phát hành”, available at http://www.gso.gov.vn/default.aspx?tabid=512\&idmid=5\&ItemID=12574

VCCI (2008), "Báo cáo chỉ số năng lực cạnh tranh cấp tỉnh của VN năm 2007”, retrieved from http://www.pcivietnam.org/uploads/report/VNCI_PCI2007_VN.pdf on Feb. 27, 2014.

VCCI (2008), "Báo cáo chỉ số năng lực cạnh tranh cấp tỉnh của VN năm 2006", retrieved from http://www.pcivietnam.org/uploads/report/Bao\%20cao\%20PCI\%202006.pdf on Feb. 27, 2014.

VCCI (2009), "Báo cáo chỉ số năng lực cạnh tranh cấp tỉnh của VN năm 2008" retrieved from http://www.pcivietnam.org/uploads/report/Bao\%20cao\%20PCI\%2008\%20day\%20du.pdf on Feb. 27, 2014.

VCCI (2010), “Báo cáo chỉ số năng lực cạnh tranh cấp tỉnh của VN năm 2009”, retrieved from http://www.pcivietnam.org/uploads/report/Bao\%20cao\%20PCI\%202009.pdf on Feb. 27, 2014.

VCCI (2011), "Báo cáo chỉ số năng lực cạnh tranh cấp tỉnh của VN năm 2010", retrieved from http://www.pcivietnam.org/uploads/report/Bao\%20cao\%20PCI\%202010.pdf on Feb. 27, 2014.

VCCI (2012), "Báo cáo chỉ số năng lực cạnh tranh cấp tỉnh của VN năm 2011", retrieved from http://www.pcivietnam.org/uploads/report/Bao\%20cao\%20PCI\%202011_final.pdf on Feb. 27, 2014. 